\title{
Instruções editoriais para os autores
}

Os autores devem seguir estritamente as diretrizes abaixo; sua não observância poderá implicar em não aceitação do artigo submetido, sendo os autores orientados a adequar o arquivo submetido aos padrões requeridos.

1. O artigo deve ser inédito e redigido em português ou em inglês. Além de inédito, o artigo não deve estar em apreciação concomitante em nenhum outro periódico ou veículo de publicação, no todo ou em parte, no idioma original ou traduzido.

2. O arquivo a ser enviado deve estar em formato.doc ou.docx; use somente a formatação padrão do texto. Os autores devem retirar sua identificação das propriedades do arquivo.

3. Não serão aceitos artigos com mais de 4 (quatro) autores/co-autores. No caso de mais de dois autores, a equipe editorial se reserva o direito de solicitar informações sobre o papel de cada um dos autores no processo de desenvolvimento do artigo.

4. O autor deve submeter três arquivos:

4.1 Um arquivo contendo título, resumos, palavras chave, corpo do texto e referências. No texto do artigo, o responsável pela submissão deve eliminar qualquer referência que possa permitir sua identificação.

4.1.1 No caso de um trabalho fruto de pesquisa financiada, o autor deve abrir uma nota de rodapé na primeira página do artigo para se referir ao financiamento e às agências de fomento que o possibilitaram.

4.2 Um arquivo, a ser submetido como suplementar, contendo a identificação dos autores, sua titulação máxima e a instituição a qual se encontra atualmente filiado, um resumo do Curriculum vitae de, no máximo, 5 linhas, contendo titulação, função que desempenha na instituição à qual é filiado e a URL do Currículo Lattes. Em casos de artigos com múltiplos autores, a informação de todos os autores deve ser apresentada. Neste mesmo arquivo, o autor poderá incluir agradecimentos, se desejar.

4.3 Uma Carta ao Editor, que deve ser enviada também como arquivo suplementar, na qual assume que o conteúdo do trabalho apresentado é inédito, não contém nada que possa ser considerado ilegal, difamatório, que cause conflito de interesses ou que possa interferir na imparcialidade do trabalho apresentado.

5. O arquivo com o corpo do texto não deve conter nenhuma forma de identificação dos autores; a formatação do texto deve estar em espaço simples; fonte de 12-pontos; uso do itálico em vez de sublinhado (exceto em endereços URL); as figuras e tabelas devem ser inseridas no texto, e não no final do documento na forma de anexos. 
6. O artigo deve conter o mínimo de 7.000 e o máximo de 8.000 palavras, incluídos título, resumo e palavras chave (em português e em inglês), corpo do texto e notas de rodapé; excluídas as referências.

6.1 Serão adotadas no máximo cinco palavras-chave em cada idioma. Elas devem se referir ao objeto de estudo do artigo e ao referencial teórico e/ou temática utilizada para análise.

7. O artigo deve incluir um resumo em português e em inglês, entre 150 a 200 palavras para cada uma das versões. Lembramos que o resumo em ambos os idiomas integra o número mínimo e o máximo de palavras, conforme indicado no item 6.

8. As notas de rodapé devem se restringir a esclarecimentos adicionais ao texto. Todas as referências de fonte bibliográfica ou outras deverão ser feitas no corpo do texto, conforme o sistema de citação Chicago (AUTOR, data).

8.1 As citações devem estar no mesmo idioma que o artigo. Assim, será acrescentada no corpo do texto a versão traduzida, e em nota de rodapé, a versão original da citação.

9. A formatação de tabelas, quadros e figuras deverá seguir o formato ABNT.

10. As referências devem ser listadas ao final do texto e devem se restringir àquelas efetivamente citadas no artigo. Deve ser observado estritamente o sistema Chicago (AUTOR, data). Não serão aceitas referências bibliográficas em notas de rodapé.

As mesmas deverão seguir os modelos abaixo, de acordo com o formato estabelecido pela NBR 6023 (2002) da ABNT.

10.1 Para artigos ou documentos eletrônicos:

Elementos: AUTOR(es). Título. Título da publicação. Local de publicação, numeração correspondente ao volume, número, mês e ano de publicação, paginação inicial e final. Indicar o endereço (link) onde o documento está disponível e a data de acesso ao artigo.

MIYAMOTO, Shiguenoli. Política Externa Brasileira: 1964-1985. Carta Internacional, v. 8, n. 2, 2013, p. 3-19. Disponível em: http://www. cartainternacional.abri.org.br/index.php/Carta/article/view/120/64. Acesso em: 14 jul. 2016.

10.2 Para Livros

Elementos: AUTORES(es). Título. Edição (a partir da $2^{\text {a }}$ edição). Cidade: Editora, ano de publicação.

SARAIVA, José Flávio S. Foreign Policy and Political Regime. Brasília, DF: IBRI, 2003. 
10.3 Para capítulos de livros:

Elementos: AUTOR(es) do capítulo. Título do capítulo. In: AUTOR(es) da obra (Org., Ed., Coord.) Título da obra. Edição (a partir da $2^{\text {a }}$ edição). Cidade: Editora, ano de publicação. Capítulo consultado e paginação da parte.

SNIDAL, Duncan. The politics scope: endogenous actors, heterogeneity and institutions. In KEOHANE, Robert O; OSTROM, Elinor. Local commons and global interdependence: heterogeneity and cooperation in two domains. London: Sage Publication, 1995. Cap. 2, p. 47-70.

10.4 Trabalhos apresentados em Eventos

Elementos: AUTOR(es). Título do trabalho apresentado. In: nome do evento, numeração do evento (se houver), ano e local (cidade) de realização, título do documento (anais, atas, tópico temático), local, editora, data de publicação e página inicial e final da parte referenciada.

VENTURA, Deisy de Freitas Lima; PEREZ, Fernanda Aguilar. A política externa de saúde de Dilma Rousseff (2011-2014): elementos preliminares para um balanço. In: $5^{\circ}$ Encontro Nacional da ABRI, 2015, Belo Horizonte. Anais Eletrônicos. Disponível em: < http://www.encontronacional2015. abri.org.br/site/anaiscomplementares?AREA = 14\%2017 > . Acesso em: 14 jul. 2016.

11. No ato da submissão, todas as informações requeridas no sistema deverão ser devidamente preenchidas.

\section{Condições para submissão}

Como parte do processo de submissão, os autores são obrigados a verificar a conformidade da submissão em relação a todos os itens listados a seguir. As submissões que não estiverem de acordo com as normas serão devolvidas aos autores.

1. A contribuição é original, inédita e não está sendo avaliada para publicação por outra revista. Caso contrário, deve-se justificar em “Comentários ao editor”.

2. O arquivo da submissão está em formato Microsoft Word, OpenOffice ou RTF.

3. URLs para as referências foram informadas quando possível.

4. O texto está em espaço simples; usa uma fonte de 12-pontos; emprega itálico em vez de sublinhado (exceto em endereços URL); as figuras e tabelas estão inseridas no texto, não no final do documento na forma de anexos.

5. O texto segue os padrões de estilo e requisitos bibliográficos descritos em Diretrizes para Autores, na página Sobre a Revista.

6. Em caso de submissão a uma seção com avaliação pelos pares (ex.: artigos), as instruções disponíveis em Assegurando a avaliação pelos pares cega foram seguidas. 